\title{
Alternative Strategies in Dealing with Conflict Management Issues in Secondary Schools in Kitwe District, Zambia
}

\author{
Clement Kasenge $^{1^{*}}$, Muleya Gistered $(\mathrm{PhD})^{2}$ \\ Zambia Catholic University \\ University of Zambia
}

*Corresponding Author: Clement Kasenge, Zambia Catholic University

\begin{abstract}
The study sought to propose alternative strategies in dealing with conflict management issues in Kitwe district, Zambia. The study was qualitative in nature identifying and exploring behaviours of actors that is motivations, opinions and attitudes. It was supported by a case study design which used interviews, Focus Group Discussions and Theatre for Development techniques to collect data from fifty two participants. A sample comprising 13 Headteachers; 13 Teacher Union leaders; 13 School Council leaders and 13 Education Board leaders was used. To collect this sample, the researcher used quota sampling method whose population was divided into the above mentioned groups. The data collected was subjected to qualitative analysis. They were analysed using thematic approach. The research question solicited data on the proposed alternative conflict management strategies in dealing with conflict management issues in schools. The main result was thatHeadteachers, Teacher Union leaders, Education Board leaders and School Council leaders should be protected from all forms of harassment.
\end{abstract}

Keywords: Systems' thinking, Conflict management, Leaders, Strategy

\section{BACKGROUND}

The world over, Zambia inclusive, is looking at practical ways of managing conflicts in educational institutions. These practical ways are termed as conflict management strategies.

According to Swanstrom and Weismann (2005), in their concept paper, provided an overview of the concept 'Conflict Management' and defined it as the limitation, mitigation or containment of a conflict without necessarily solving it. They also contend that conflict management should imply a change from 'destructive' to 'constructive' in the mode of interaction. Changing the mode of interaction from destructive to constructive creates confidence building measures which are crucial as they serve to strengthen the conflict management process by increasing trust among actors. Jeong, (2011) on the other hand, expresses that a conflict has been broadly associated with tension surrounding decisions on various choices, sometimes being manifested in confrontations between social forces and that coping with conflicts particular ways such as strategies are employed. In other words, a strategy serves as an overall plan to responding to a given situation. Therefore, conflict management strategies are designed to control costly struggle in order to minimise negative impacts of unstrained forces. The goal of conflict management strategies is the promotion of harmonious relationships in the social environments like schools (William, 2005). UNESCO (2000) is in support of this goal in that it encourages changing the vision of the world, the way of communicating and living together in educational institutions. Furthermore, William (2005) advises that we must apply cogs of the machine thus: systems, structures and policies. This, according to him, is termed as systems' thinking. He defines systems' thinking as a conceptual framework, body of knowledge and tools to make the full patterns clear and help people see how various parts of the system that is:

1. Actors- Headteachers, Teacher Union leaders, Education Board leaders and School Council leaders;

2. Structures- Secondary schools and positions held by people;

3. Mechanisms- ways these actors and structures operate together. 
In short, in systems' thinking people are looking for patterns in the way that the different parts of the system interact and influence each other.

The premise of UNESCO is that friction and conflict will always exist in educational institutions, the wellbeing of which does not so much depend on conflict but on the ability, to 'identify it', tackle it' and 'find solutions'. UNESCO is encouraging institutions to initiate best practices for conflict management. These practices are aimed at informing Headteachers, teachers, parents and pupils, who one way or another, are confronted with conflicts in schools in order to look for practical solutions to manage conflicts. The intention of UNESCO is to inform stakeholders what is best in terms of education and supply pedagogical tools to manage conflicts which they are confronted with on a daily basis. UNESCO emphasises that each institution must establish its own conflict management strategies depending on its own local situation. This means that it is not just a matter of using conflict management strategies such as compromising, co-operation, avoiding and confrontation.

The Zambian Ministry of General Education has also come up with the idea of promoting democracy and partnership (MoGE, 1996) Educating Our Future Policy. According to this policy, "democratisation of Education, with its demands for partnership in educational provision, requires that the government creates an enabling environment and establishes rules and regulations that will protect the rights of various educational agencies to full and fair participation in educational development" (MoGE, 1996:2). This means that parents', pupils', teachers' and Headteachers' rights are given full and fair participation and are protected in the Ministry of General Educational system. To support this idea, Jensen and Schnack, (1994) has called this 'action competence' meaning that the individual is able and willing to be a qualified participant. The Ministry of General Education's encouragement on the issue of democracy is also supported by Dewey, (1916) who has been a great inspiration for many theorists as well as practitioners, democratic leadership means that democracy is lived through participation in the everyday practice of school life. He encourages 'deep' democracy which allows for free and open inquiry and critiques, recognition of interdependence in working for the common good.

All the above are leading into encouraging education leaders to be democratic in their leadership as they execute their duties. It is a well-known fact that where democracy lacks, conflicts are prominent. In the research done by (Mulford, 2005) suggests, on the basis of findings from a large Australian school leadership research project, that reforms should be related to the following factors:

(i) Distributed leadership- Teachers, Pupils and Parents should be involved in leadership in order to feel cared for and valued and be given opportunities to be involved in decision making.

(ii) Development and learning- A unifying focus and shared insights into what the school is doing and why it is doing it provides the basis for proper management of conflicts in schools.

Bernstein, (2000) also gives an insight of the main purpose of school leadership whose premise is to empower and enable staff and students to assume responsibility for learning, acting and collaborating in school and outside school. He strongly emphasises on the point of democracy.

Lastly, the inclusion of democracy in the 1996 Educating Our Future Policy is a very serious conflict management strategy which is meant to help school leaders such as Headteachers, Teacher Union leaders, School Council leaders and Education Board leaders manage conflicts in their respective schools. One wonders, are they utilising this conflict management strategy put in place by MoGE to manage conflicts reported from time to time? What conflict management strategies do they use? These are questions which need answered. Therefore, the focus of this study was to propose alternative strategies in dealing with conflict management issues in Kitwe district, Zambia.

\section{Purpose of The Study}

The purpose of the study was to propose alternative strategies in dealing with conflict management issues in secondary schools in Kitwe district, Zambia. 


\section{CONCEPTUAL FraMEWORK}

A conceptual framework represents the researcher's synthesis of literature on how to explain a phenomenon (McGaphie et al, 2001). It maps out the actions required in the course of the study given his/her previous knowledge of the other researchers' points of view and their observations on the subject of research.

In other words, the conceptual framework is the researcher's understanding of how particular variables in his/her study connect with each other. It is the researcher's map in pursuing the investigation.

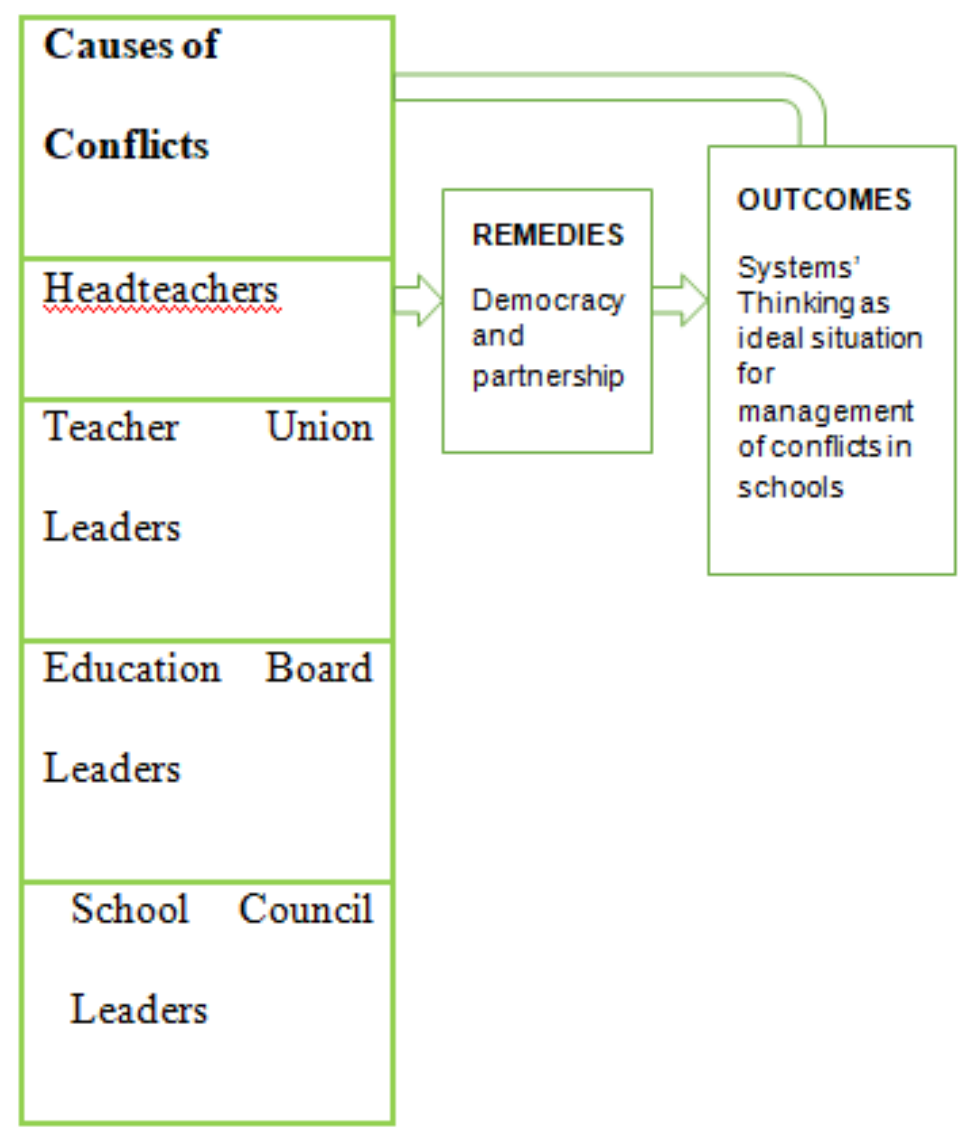

The model above shows Headteachers, Teacher Union leaders, Education Board leaders and School Council leaders as causes of conflicts. If these people work together in a democratic way and partner together they will create "systems' thinking" which is an ideal situation for the management of conflicts in schools.

\section{THEORETICAL FRAMEWORK}

Schools, in the management of conflicts, have sought to develop universal or generic theories to explain the existence of conflicts at every level of social interaction: between individuals, groups, institutions and state or society.

The researcher discussed one theory that guided this study: This theory was particularly directed at managing conflicts in schools. Therefore, it guided the researcher in exploring the effectiveness of managing conflicts in the Zambian Educational System.

\subsection{Basic Human Needs Theory of Conflict}

According to Burton, (1990) the core assumption for many people working on conflict management is the belief that humans need a number of essentials to survive and thrive. If these needs are denied, they will strive to attain them by any means necessary.

Burton developed 'Basic Human Needs' theory of deep routed conflict that are seen as affecting every sphere of human existence. According to him, human needs are in born and are a part of the basic make-up of every human being as the elemental requirements for human development, as such; they 
are both universal and trans-historical, relevant to every community at every point in human history. He categorized identity and security as the core of basic human needs.

The quest to satisfy these needs is the basic 'drive' for human motivations and behaviour. They will be pursued by all available means, of seemingly 'irrationally' and against all odds.

He believes that attempts to suppress needs, usually involving some form of coercion will never be successful in the long-term in any given institution. Attention must instead be directed to developing systems that satisfy these needs. While the needs themselves are generic, the satisfiers of these needs are contextually specific. Because needs for identity and security do not pertain to scarce resources, it is possible to satisfy the needs of all stakeholders through integrated outcomes. (For example, we can both be more secure if we each support each other's identity and security; ('my identity can co-exist with your identity'). There is, therefore, a presumption that a satisfactory end state can be reached. Yet it is not possible for an outsider to prescribe what will fulfil the need requirements of another individual or group; they must identify those satisfiers themselves. Burton argues that this can only be done through inclusive processes. All stakeholders must be involved in dialogue to identify underlying needs and the means for satisfying them.

Burton does not focus on power dynamics or recognize the existence of asymmetries in the relationships between those in conflict. He tends to assume that the costs of conflict are high for all stakeholders and that each will willingly implement good agreements because their needs are also satisfied by it. This presumes a degree of rationality in analysing the problem and developing an integrated outcome. Burton and those who follow this approach, have tended to focus on the integrity and efficiency of the process that brings those in conflict towards reaching mutually agreed outcomes, rather than adherence to seemingly abstract principles. This means that groups at some point become unresponsive to the needs of other groups and in this case, the basic communal needs are for:

a. Acceptance; recognition of the group's unique identity as expressed in their values.

b. Access; to effective participation in decision-making institutions.

Burton believed that if groups were unresponsive, it weakened the institution's capacity to respond to and meet the needs of various groups. Ironically, because of failure to meet these basic needs adequately, the institution often remained weak and vulnerable to challenges. He observed that, however, that often the situation could remain relatively stable until some event occurred that acted as a catalyst for mobilizing the groups to take action to address these conditions (much in the way that a conflict may be 'latent' in the institution until some triggering event occurs that reveals its existence). Conflict becomes persistent and does not go away completely unless the basic needs of identity and security are met.

In this context, actors (individuals and groups) always act in the pursuit of their own interests. Associated with this idea is the assumption that actors will aim to maximize their power over all other actors so as to have a competitive advantage over them, in a framework that assumes that there are almost inevitably winners and losers. This theory is supported by other studies when they suggest that there is no such a thing as altruism or other forms of unselfish behaviour because everyone is trying to pursue their interests and have exterior motives (Coser, 1956). Other studies support this theory when they suggest that institutions have different identity groups who are unresponsive to the needs of other groups (Azar, 1990). He believed that if groups did not respond to and meet the needs of other groups, the institution was weakened. In this case, Azar found out that if groups remained rigid by failing to meet these basic needs of identity and security, the institution remained weak and vulnerable to challenges. He observed, however, that often the situation could remain relatively stable until some event occurred that would act as a catalyst for mobilising the group to take action to address these conditions, much in the same way that a conflict may be latent in the institution until some triggering event occurred that would reveal its existence. He contended that conflict became persistent and did not go away completely unless the basic needs of identity and security were met.

This theory supports the idea that secondary schools in Zambia are Education Boards and have leaders who are divided into groups. These groups are: Headteachers; Teacher Union leaders; Education Board leaders and School Council leaders, who each has the need to protect their identities and security. Burton argued that failure to satisfy these identities and security led to dysfunctional development, frustration and protracted conflicts. 
The Ministry of General Education encourages democracy and partnership in Education Boards in order to ensure that the above mentioned leaders co-exist, but there are still conflicts reported from time to time in these institutions (MoGE, 1996). This is a problem in the Ministry of General Education. The Ministry of General Education wants these leaders to be democratic and believes that democracy can play a major role in achieving co-existence among these leaders because democracy enables groups to respect needs of identities and security.

In this study the assumption was that successful management of conflicts was centred on using conflict management strategies that would encourage Headteachers, Teacher Union leaders, Education Board leaders and School Council leaders to co-exist by being responsive to each other's identities and security.

This study adopted Swanstrom's and Weismann's (2005) definition of conflict management strategies as 'Changing from destructive to contructive' in the mode of interaction in order to make actors live together in harmony. This definition fits this theory.

\section{MeTHOdOLOGY AND DESIGN}

Cresswell (2012) stated that a research design is the specific procedure employed in carrying out a research process. It involves the collection of data, data analysis and report writing. Chola (2016) also contended that a research design is a frame work in the whole process of research aimed at pointing the researcher in the direction of that research. Since this study endeavour to generate opinions regarding the management of conflicts in single institutions, a case study design was adopted. A case study design, according to Marczk et al (2005) involves an in depth examination of a single person of a few people. It provides an accurate and complete description of the case. Case studies also involve the intensive study of an individual, family, groups, institution or other level which are conceived as a single unit. The information is highly detailed, comprehensive and typically reported in narrative form as opposed to the quantified scores on a dependant measure. This research design was ideal for this study as it allowed this investigation to focus on the specific case and understand it in detail. The researcher used interviews, focus group discussions and theatre for development techniques to collect data from fifty two participants. A sample comprising 13 headteachers, 13 teacher union leaders, 13 school council leaders and 13 education Board leaders was used. To collect this sample the researcher used quota sampling method whose population was divided into the above mentioned groups. The data collected was subjected to qualitative analysis, they were analysed using thematic approach.

\section{Presentation And Discussion OF Findings}

\subsection{What Alternative Conflict Management Strategies can be Proposed in Dealing With Conflict Management Issues In Schools?}

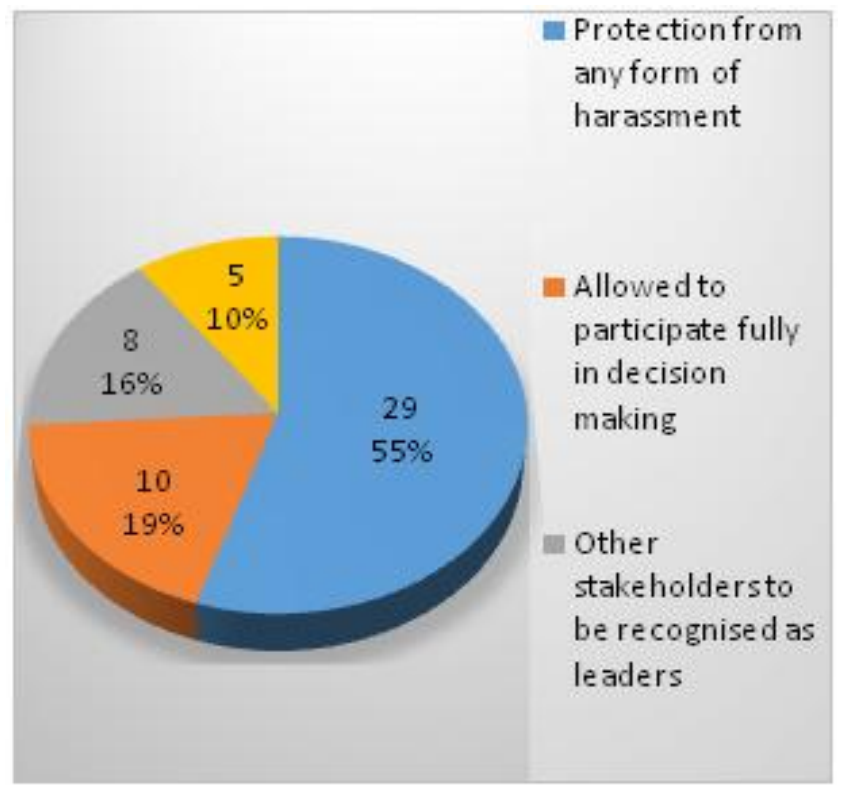

Figure1. Responses from participants on the proposed alternative conflict management strategies in dealing with conflict management issues in schools 
Figure 1 above shows responses from participants on the proposed alternative conflict management strategies in dealing with conflict management issues in schools. 55\% represents 29 participants out of 52 participants who stated that they should be protected from any form of harassment. $19 \%$ represents 10 participants out of 52 who said that they should be allowed to participate fully in decision making in schools. $16 \%$ represents 8 participants out of 52 participants who said that apart from Headteachers other stakeholders should be recognised as leaders. 10\% represents 5 participants out of 52 participants who said that Teacher Unions, Education Boards and School Councils should be strengthened.

Teacher Union leaders stated that they should be protected from any form of harassment in order for them to participate freely as they represented their members. Education Board leaders, Teacher Union leaders and School Council leaders said that they should be allowed to participate fully in decision making in schools. Furthermore, they said that apart from Headteachers, other stakeholders should be recognised as leaders and that Teacher Unions, Education Boards and School Councils should be strengthened. It is also evident that Headteachers should also be protected from attacks by Education Board leaders, Teacher Union leaders and School Council Leaders because emphasis on protection was just centred on other leaders.

\section{One Teacher Union Leader Had This to Say:}

In the first place, we would like our Headteachers to recognise us as leaders and that Teacher Unions should be used to manage conflicts in schools as long as we are involved in decision making. We want Teacher Unions to be strengthened so that our Headteachers know that the government has done its part by recognising us as leaders. Together, we can build our schools. Headteachers should stop the habit of threatening us by telling us that they will surrender and transfer us. It is a request with due respect as we you know that these are our leaders, to help us represent our members fully on matters affecting them.

\section{One Education Board Leader Had This to Say:}

As for us, the major complaint is that we are not very much involved in decision making as far as we are concerned. We are also requesting Headteachers to take establishment of Education Boards seriously, otherwise as parents, we are not happy with the way Education Boards are running as government wants them to run. Instead of working together, we have no say in certain areas, especially when it comes to school fees. Sometimes we just receive letters that fees have been hiked and this scenario has created conflicts. We need to be treated as leaders too. Let us work together as a team.

\section{One School Council Leader Had This to Say:}

School Councils are just on paper. In some schools, they are not even there. All we are told is that there is no need for School Councils since the Headboy and the Headgirl are already on the Education Board representing their fellow pupils, but we want an independent body with its own elected members. We want to be given a voice. Our teachers think they can think on our behalf. Sometimes we do not co-operate with them because they do not involve us in decision making. When we complain to the administration concerning teachers who do not want to teach, the teachers we complain against, threaten us. If we had a body, we would be protected. If School Councils are fully in place, we will be happy and even the riotous behaviour you hear about in newspapers will go.

\section{One Headteacher Had This to Say:}

I feel Teacher Union leaders, Education Board leaders and School Council leaders do not appreciate us. What do I mean? On the side of Teacher Union leaders, the problem is that they want to win all the time. Whatever they want to achieve, should be achieved against all odds. For example, I do not want to go into details here. Just as much as we appreciate Teacher Union leaders are leaders, but they should bear in their minds that they are our subordinates. Anyway, I appreciate the way the Union leader, who is with us here, addressed us. This is how it should be. I wish all the other Union leaders did the same. Let me not dwell much on this one. What I am emphasising on is that they should approach us with respect. Sometimes they approach us as if we are not their superiors. That is why sometimes we create barriers by ignoring them. 
If we are to work together with Teacher Union leaders in order to uphold democracy and partnership, they should ensure that they also respect us by understanding our superior positions. On the side of Education Board leaders, I feel on behalf of my fellow Headteachers, we hold meetings all the times. Education Board meetings are scheduled every year. We are all Secretaries of Education Boards. The meetings are chaired by Education Board Chairpersons. This is simply indicating that Education Board leaders are involved or allowed to participate in school matters. I feel the problem is that they want us to accept everything they say. It is not just possible. They must understand that Headteachers cannot accept everything. On the issue of school fees, most of the times parents want to pay very little, but school requirements have gone up. When we try to reason with them, they react negatively. What we would like to see in these leaders is that they should be democratic too by allowing us to express our views. Like this, we will be able to move together. On the side of our pupils, you should not worry in anyway; we will address your concerns.

Apparently, the findings are in agreement with Ting-Toomey (2001) who found out that the core values of an organisation include: respect for hierarchy; building relationships through reciprocal obligations. Generally speaking, where there is group orientation and harmony, conflicts may be minimised. In building relationships, (Hodgkinson, 1991), advises school leaders to lead and manage with proper reference to the broader environmental context of their communities. It is evident from findings that the mentioned leaders were not consistent or compatible with each other and this has led to the generation of inconsistencies and conflicts reported from time to time in these schools. Therefore, it is a fact that trust is nurtured through relationships, through information and through knowledge. From the findings, these leaders have concentrated on enhancing teaching and learning and fostering relationships comes at the bottom of their priorities, yet it is through mutuality that stakeholders sign up to common goals. Trust is the super glue that binds these elements together and connects the school's internal community with its outside communities. According to Riley and Stoll, (2005), trust cannot be assumed, but it has to be created and it has to be earned. Louis and Kruse, (1995), indicate that educational reforms are doomed to fail, unless trusting relationships are present among teachers, school leaders, parents and students. They further indicate that trust is leadership in response to the community.

These sentiments are also supported by Mulford (2005) who suggested, on the basis of his findings from a large Australian school leadership research project, that reforms should be related to one factor of distributed leadership. According to him, teachers should be involved in leadership in order to feel cared for and valued and to be involved in decision making. This factor indicates that development and learning should be a unifying focus and shared insights into what the school is doing and why it is doing it. By so doing, Teacher Union leaders are able to co-operate with Headteachers. It is evident that Teacher Union leaders are operating in fear and that there is no co-existence. This is against the 1996 Educating Our Future Policy that encourages and strengthens partnerships and democracy in educational development.

On the side of School Council leaders, they indicated that they should be involved in decision making. Their sentiments were in line with Save the Children (2002) which pointed out that girls and boys had the right to be involved in decisions affecting them. Furthermore, Government should ensure that girls' and boys' views are sought and considered in all matters that affect them. It further indicated that children of any age should be allowed to express their views. This means that decision making bodies, other institutions and families must listen to children and take their views. Contributing to conflict management strategies, Save the Children (2002), asserts that if children participate in matters affecting them it may help manage conflicts in schools as School Councils help children to co-operate with adults and fellow children. Save the Children also indicated that the whole ethos of the school changed as pupils exerted a positive influence over one another through the structures that gave them responsibility for decision making. Furthermore, it indicated that anti-social behaviour became the responsibility of the class and consequently the authority of anti-social groups diminished. They concluded that teachers were able to spend less time tackling issues such as bullying, disruptive behaviour, truancy, vandalism and exclusions and teachers had more time for teaching, stress levels reduced, relationships between teachers and pupils improved and the learning environment became 
more effective. In this case, pupils felt responsible as partners in their own education and were able to make the most of the learning opportunities offered by the schools. Therefore, involving School Council leaders in decision making could be an alternative conflict management strategy which would protect them from any form of harassment.

\section{CONCLUSION AND RECOMMENDATIONS}

\subsection{Conclusion}

As a reminder to readers, this study was looking at proposed alternative conflict management strategies in dealing with conflict management issues in schools. The main result was that if Headteachers, Teacher Union Leaders, Education Board Leaders and School Council Leaders would live together if each group was protected from all forms of harassment.

\subsection{Recommendations}

- Headteachers, Teacher Union leaders, Education Board leaders and School Council leaders should be protected from all forms of harassment.

- Headteachers, Teacher Union leaders, Education Board leaders and School Council leaders should avoid ignoring each other.

\section{REFERENCES}

[1] Azar,E., (1990). The Management of Protracted Social Conflict: Theory and Cases. NewYork: Dart Mouth Publishing Company.

[2] Bernstein, B., (2000). Pedagogy, Symbolic Control and Identity:Theory, Research and Critique. Lanham:Rowman and Littlefield.

[3] Burton, J., (1990). Conflict: Human Needs' Theory. New York: St Martin's Press.

[4] Chola, D. K., (2016). Assessment of Service Learning in the Teaching of Civic Education in Selected Secondary Schools in Lusaka Province, Zambia.Unpublished M Ed Thesis, Lusaka: University of Zambia.

[5] Coser, L., (1956). The Functions of Social Conflict. London: Routledge and Kegan Paul.

[6] Creswell, W. J., ( 2012). Education Research: Planning, Conducting and Evaluating Qualitative Research, 4th Edition. NewYork:Pearson Education Inc.

[7] Dewey, J. (1916). Democracy in Education. NewYork:Macmillan.

[8] Hodgkinson, G.P., (1991). The Competent Organisation. Maidenhead:Open University

[9] Jensen, B.B. and Schnack, K., (1994). (Didaktiskestudier.Studies in Educational Theory and Curriculum:nr. 12). In Jensen,B.B, Action Competence as Key Concepts in Critical Pedagogy (pp. 5-18). Copenhagen:Denmarks La Rerhijsokole.

[10] Jeong, H., (2011). Understanding Conflict and Conflict Analysis. London: SAGE Publications Ltd.

[11] Marczyk, G., et al., (2005). Essentials of Research Design and Methodolgy, Kaufmaman, A.S. and Kaufman, N.L., (editors). Hoboken, New Jersey: John Willey and Sons, Inc.

[12] McGaphie, W. C. et al., (2001). Conceptual Framework:A step by step Guide on How to make One. NewYork: Pearson Education Inc.

[13] MoGE., (1996). Educating our Future Policy. Lusaka: Government Printe

[14] Mulford, B., (2005). Leadership for School and Student $\mathbf{L}$

[15]Riley, K.A., and Stoll, L., ( 2005). Leading Communities: Purposes, Paradoxes and Possibilities. Professional Lecture. London: Institute of Education.

[16] Save the Children., (2002). Promoting Children's Meaningful and Ethical Participation in UN Global Study on Violence. A short Guide for Members of the NGO Advisory Panel and Others.

[17] Swanstrom, L. P. N. and Weismann, M. S., (2005). Conflict Prevention and Conflict Management and Beyond: A Conceptual Exploration. Sweden: Central Asia - Caucasus institute.

[18] Ting-Toomey, S., (2001). Managing Intercultural Conflicts Effectively. Thousands Oak. CA:Sage.

[19] UNESCO., (2000). Best Practices of Non-Violent Conflict Resolutions in and out of School. France:UNESCO.

[20] William, S., (2005). Conflict, Power and Change: Engaging Actors, Systems, Structures and Policies. Amsterdam: Boonruang Song - Ngam. 
Alternative Strategies in Dealing with Conflict Management Issues in Secondary Schools in Kitwe District, Zambia

\section{AUTHOR'S BIOGRAPHY}

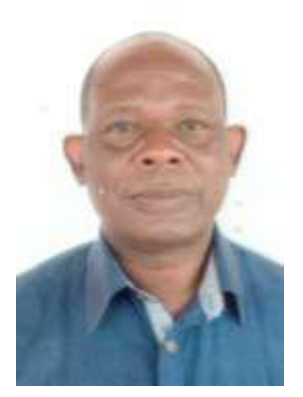

I am Clement Kasenge. I was born on 3rd October 1959. At the moment, my highest qualification is Master of Education degree in Literacy and Development.

I am pursuing a $\mathrm{PhD}$ degree with University of Zambia in Education Administration and management and about to graduate.

My research interest is in Humanities, Social Sciences and Education

Citation: Clement Kasenge, Muleya Gistered (PhD). "Alternative Strategies in Dealing with Conflict Management Issues in Secondary Schools in Kitwe District, Zambia" International Journal of Humanities Social Sciences and Education (IJHSSE), vol 7, no. 2, 2020, pp.37-45. doi: http://dx.doi.org/10.20431/23490381.0702005.

Copyright: () 2020 Authors. This is an open-access article distributed under the terms of the Creative Commons Attribution License, which permits unrestricted use, distribution, and reproduction in any medium, provided the original author and source are credited. 